\title{
Ápolók transzfuziológiai ismeretei és kompetenciái egy országos felmérés tükrében
}

\author{
Rajki Veronika ${ }^{1,4}$. Csóka Mária ${ }^{1}$ - Deutsch Tibor dr. ${ }^{2}$ \\ Mészáros Judit dr. ${ }^{3}$ \\ Semmelweis Egyetem, Egészségtudományi Kar, ${ }^{1}$ Alkalmazott Egészségtudományi Intézet, Ápolástan Tanszék, \\ ${ }^{2}$ Képalkotó Diagnosztikai Analitikus és Orvostechnikai Tanszék, Budapest \\ ${ }^{3}$ Semmelweis Egyetem, Egészségtudományi Kar, Alkalmazott Egészségtudományi Intézet, Budapest \\ ${ }^{4}$ Semmelweis Egyetem, Doktori Iskola, Budapest
}

Bevezetés: Nemzetközi szakirodalmi adatok egyértelmúen bizonyítják, hogy a transzfúziós terápiában folyamatosan nő az ápolók szerepe, amelyet kizárólag komoly szakmai ismeretek és készségek birtokában tölthetnek be. Célkitüzés: A szerzők a transzfúziós terápia gyakorlatának, az ápolók transzfúziós terápiával, valamint saját kompetenciáik meghatározásával kapcsolatos ismereteinek országos szintű feltérképezését tűzték ki célul. További céljuk a hasonlóságok és különbözőségek feltárása volt a kutatás idején hatályos Transzfúziós Szabályzat (2008) előírásainak betartására vonatkozóan. Módszer: A 2014. november 19. és 2015. február 20. közötti intervallumban végzett országos reprezentatív felméréshez saját készítésû kérdő́ivet alkalmaztak. Az adatgyújtést papír- és webalapú anonim, önkitöltős, standardizált körülmények között, rétegzett mintavételi technikával végezték. A vizsgált mintába $(\mathrm{n}=657$ fő $)$ olyan ápolókat vontak be, akik felnőtt fekvőbeteg-osztályon, változó rendszerességgel vettek részt transzfúziós terápiában. A keresztmetszeti kutatás adatait első lépésben leíró statisztikai eljárások segítségével dolgozták fel. Eredmények: Megállapították, hogy a vizsgált minta transzfuziológiával kapcsolatos ismeretei erősen hiányosak (50,72\%), az ápolási funkciókat csak az ápolók fele (52,3\%) rendszerezte helyesen, és jelentős különbségek voltak a transzfúziós terápia gyakorlatára vonatkozóan is. A vizsgált intézmények túlnyomó többsége rendelkezett saját protokollal, de a betegosztályok mindössze 23,9\%-án dolgozott megbízott transzfúziós felelős ápoló. Következtetések: A szerző́k a feltárt problémák megoldását az ápolók szakmai felelősségének növelésében, az ápolás vezetőinek a jelenleginél nagyobb mértékű felügyeletében, a megfelelő transzfuziológiai képzés és rendszeres továbbképzés biztosításában látják. Orv. Hetil., 2015, 156(34), 1383-1392.

Kulcsszavak: ápolói kompetencia, transzfúziós terápiával kapcsolatos ismeret, transzfúziós terápia gyakorlata, vérbiztonság, betegbiztonság

\section{Transfusiology-related knowledge and competence of nurses in the light of a national survey}

Introduction: International literature data clearly show that the role of nurses in transfusion therapy, which needs professional knowledge and skills, continues to increase. Aim: The aim of the authors was to perform a nationallevel mapping of the practice of transfusion therapy including transfusion therapy-related knowledge of nurses and their knowledge about their competence. Further aim was to identify similarities and differences as referred to the requirements of the transfusion regulations (2008), which was valid at the time of the survey in Hungary. Method: The nationwide survey took place between November 19, 2014 and February 20, 2015. Data were collected using paper-form and web-based anonymous, self-administered questionnaire. 657 nurses who were involved in transfusion therapy with changing regularity in adult in-patient wards took part in the survey. Data were processed using descriptive statistical methods. Results: It was found that the transfusion therapy related knowledge of nurses was very incomplete $(50.72 \%)$, and only about half of the nurses $(52.3 \%)$ systematized the nursing functions correctly. Significant differences were also found in the practice of transfusion therapy. The vast majority of the institutions had their own protocol, but responsible nurses assigned for transfusion care were present only in $23.9 \%$ of the wards. 
Conclusions: The authors conclude that the identified problems can be resolved by improving professional responsibility of nurses, increasing supervision by nursing leaders and appropriate transfusiology training and regular retrainings.

Keywords: nursing competency, transfusion-related knowledge, transfusion therapy in practice, blood safety, patient safety

Rajki, V., Csóka, M., Deutsch, T., Mészáros, J. [Transfusiology-related knowledge and competence of nurses in the light of a national survey]. Orv. Hetil., 2015, 156(34), 1383-1392.

(Beérkezett: 2015. május 28.; elfogadva: 2015. június 29.)

\section{Rövidítések}

ATR = akut transzfúziós szövődmények; RFID = (radio frequency identification) rádiófrekvenciás azonosítás; SHOT = Serious Hazards of Transfusion

Napjainkban a vérátömlesztés biztonsága aktuális és rendkívül fontos téma az egészségügyi ellátórendszerben. A vérbiztonság egyszerre jelenti az ellátás biztonságát, a készítmény biztonságát, valamint azt is, hogy a transzfúziós folyamat nemkívánatos események nélkül történik [1]. A betegbiztonság fokozása érdekében a transzfúziós terápia során a gyógyszerelés 8-as szabályának megfelelően járunk el: a megfelelő vérkészítményt, a megfelelő betegnek, a megfelelő adagban, a megfelelő időben, a megfelelő okból, a megfelelő helyre, a megfelelő dokumentálás mellett és a megfelelő reakció kiváltásával alkalmazzuk [2]. Sajnos, a legnagyobb körültekintés ellenére is történnek transzfúziós terápiával kapcsolatos hibák, úgynevezett misztranszfúziós események. A transzfuziológia egyik legfontosabb kérdése a hemovigilancia, amelynek fogalma a hazai Transzfúziós Szabályzat (2008) szerint: „olyan követési, nyilvántartási rendszer, amely felöleli a teljes transzfúziós folyamatot a vérgyújjtéstől a vérkészítmény-elóállításon át a betegig (vénától vénáig), beleértve a súlyos káros vagy váratlan eseményeket, a súlyos szövődményeket, mind a recipiens, mind a donor vonatkozásában, valamint a donorok epidemiológiai nyomon követését" [3].

A nemzetközi gyakorlatban az úgynevezett misztranszfúziós eseményeket a felelős szervek, szakmai szervezetek felé jelenteni kell. Ilyen szervezet például a Serious Hazards of Transfusion (SHOT), amelyet az Egyesült Királyságban alapítottak 1996-ban azzal a céllal, hogy bizonyítékokkal lehessen alátámasztani a vér biztonságával kapcsolatos politikai döntéseket, szakmai irányelveket és az orvosok képzését $[4,5]$. A SHOT adatai szerint 2007-ben 10 000-ből 4,8 esetben, 2011-ben 10 000ből 11,6 esetben volt probléma a vérkomponensekkel. Ezen időszakban több mint 3000 nem megfelelő vértranszfundálási esetet jelentettek, amelyek között nemcsak olyan esetek szerepeltek, amelyeknél a betegeket nem a megfelelő (azaz valójában másik betegnek szánt) vérkomponensekkel transzfundálták. Ezen események mindegyike megelőzhető lett volna. 2011-ben az akut transzfúziós reakciók (ATR) fordultak elő leggyakrabban a káros és előre nem látható események között, és szintén ezek voltak a fő okai a jelentős morbiditásnak [6].

A SHOT 2013. évi jelentésének adataiból látható [7], hogy az 1996-tól 2012-ig terjedő időszakban a nem megfelelő vérkomponensek transzfundálása (IBCT) fordult elő a legnagyobb arányban (3336 eset), ezt követte az akut transzfúziós szövődmények (ATR) csoportja (2703 eset). 2013-ban az anti-D-immunglobulin (354 eset) és az akut transzfúziós szövődmények (320 eset) álltak a statisztikai adatok élén [8].

A transzfúziós terápia kapcsán fellépő hibák miatt a SHOT ajánlása a következő: mivel a legtöbb olyan eset, amely a nem megfelelő vérkomponensek transzfundálásából adódik, összetett hibából ered, és multidiszciplináris transzfúziós folyamat során lép fel, valamennyi részt vevő szakembernek független és alapos ellenőrzéseket kell végrehajtania az érintett betegekkel kapcsolatban. Egy egyszerü, 5 pontból álló segítő memoár alkalmazása a folyamat utolsó lépéseként emlékeztetheti a szakembereket a helyes betegazonosításra és az elrendelt vérkomponens ellenőrzésére, valamint a különleges követelményekre [7].

A National Transfusion Practitioner Survey of England and North Wales (2010) szerint sokoldalú megközelítésre van szükség a betegbiztonság növeléséhez és a transzfúziós kockázatok mérsékléséhez [6].

A Report for the Australian Council for Safety and Quality in Health Care 2005 februárjában a transzfúzió biztonságának növelése érdekében azt javasolja, hogy a jövőben nemcsak a vérkészítmények minőségével, hanem a klinikai transzfúziós gyakorlat javításával is foglalkozni kell, ugyanis 2005-ben a transzfúzióból eredő legjelentősebb kockázatok a nem biztonságos klinikai transzfúziós gyakorlattal álltak összefüggésben [9].

A biztonság fokozásában a kórházi transzfúziós teamnek van/lenne nagy szerepe a SHOT szerint [7]. Ennek keretében a SHOT 2004-ben kórházi transzfúziós szakemberek (például szakápoló vagy orvosbiológus) alkal- 

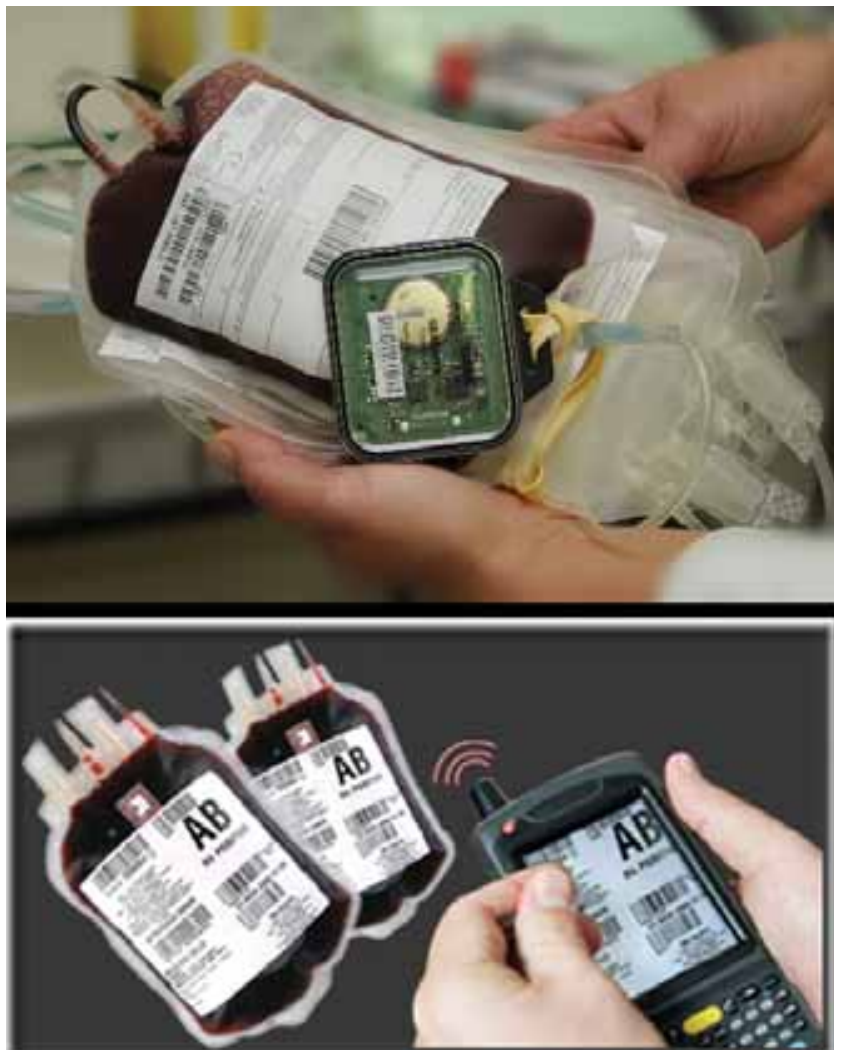

1. ábra

| RFID-címkék [14]

mazását javasolta. Hasonló igényt fogalmaztak meg Ausztráliában is, ahol a kellően képzett orvosi személyzet mellett lehetőség szerint egy képzett transzfúziós ápoló (vagy ővele egyenértékű kolléga) alkalmazását látnák célszerünek. Ezek a kórházi transzfúziós szakemberek, a vérátömlesztés vezető tanácsadóival és a helyi vérbank vezetőivel együttmúködve, támogatni tudják a klinikai teamet a vér biztonságos és hatékony felhasználásában, megkönnyítik az incidensek jelentését és az esetleges hibák, kvázi balesetek („near-miss” esetek) nyomon követését [10, 11].

A transzfúziós teamek részt vesznek a betegek biztonságát növelő új technológiák bevezetésében is $[10,11]$. Utóbbiak között a rádiófrekvenciás azonosításhoz (radio frequency identification - RFID) kapcsolódó technológiák jelentős előrelépést hoznak a transzfúziós medicinában. Alkalmazásuk a vonalkódokhoz képest praktikusabb, technikailag könnyebb és a költségük is elenyésző. A vérkészítményeken lévő vonalkódok helyett ma már több intézményben is alkalmazzák az RFID-címkéket, amelyek tervezésénél speciális körülményeket (például centrifugálás és besugárzás) is figyelembe kell venni. A címkék használatával csökkenteni lehet a tévesztéseket a transzfúzió során [12]. Briggs és mtsai közleményében egy komplex RFID-rendszer leírása is megtalálható [13]. $\mathrm{Az}$ 1. ábrán az RFID-címkék alkalmazása látható [14].

\section{Az ápolók szerepe a transzfúziós gyakorlatban}

Spanyolországban a helyi Regional Haemovigilance Division statisztikai adatai szerint az elmúlt években fokozatos növekedés volt jellemző a misztranszfúziók és a helytelen vérkomponens-transzfúziós események számában, ezért a szakemberek egy felmérést kezdeményeztek az ápolók körében, hogy tanulmányozni lehessen ennek okait. A 2007-2009 között történt felmérésnél anonim, önkéntes kérdőívet alkalmaztak, amelynek kérdései a társadalmi-szakmai tényezőkre, a transzfúziós képzésre és oktatásra, továbbá a szakmai irányelvekkel, valamint az ápolók attitüdjével kapcsolatos és azokkal nem kapcsolatos transzfúziós gyakorlatra vonatkoztak. A felmérésben a válaszadási arány 59,12\%-os volt, a 614 fóből végül 363 fó vett részt a kutatásban. A vizsgálat során többváltozós regresszióval elemezték a különböző tényezők hatását a transzfúziós hibák előfordulására és megállapították, hogy a helytelen vérkomponens-transzfúzió előfordulása összefügg az ápolóképzés színvonalával, a transzfúziós terápia gyakoriságával és az ápolók attitűdjével. Azon jól képzett ápolók körében, akik naponta vagy hetente vesznek részt transzfúziós terápiában és szigorúan betartják a transzfúziós irányelveket, szignifikánsan kisebb mértékben fordultak elő misztranszfúziós események $(\mathrm{p}<0,01)$. Ez a tanulmány jól szemlélteti a hemovigilancia alkalmasságát a misztranszfúzió okainak feltárására [15].

Egy másik tanulmány célja az volt, hogy felmérje a transzfúziós személyzet attitűdjét az egyes transzfúziós események jelentésével és a betegbiztonság kultúrájával kapcsolatban. 945 transzfúziós személy vett részt a felmérésben 43 amerikai egyesült államokbeli és 10 kanadai kórházi transzfúziós szolgáltatótól. A teljes válaszadási arány 73\% volt (693 fó). A tanulmány olyan problémákkal foglalkozik, mint például: bejelentett betegkárok (91\%), illetve az esetlegesen ártalmakat okozó ki nem javított hibák (79\%). A válaszadók kevesebb mint egyharmada tett említést olyan nem megfelelően kivitelezett tevékenységről, ami végül nem okozott potenciális kárt (31\%), valamint olyan hibákról, amelyeket maga a személyzet észlelt és maga is korrigált (27\%). A felmérésbe bevont kollégák megítélése szerint a hibák leggyakoribb oka a megszakítások (51\%) és a más betegosztályon dolgozó személyzet részéről a megfelelő eljárások hiányos ismerete vagy annak nem értése (49\%) voltak. A személyzet hozzáállása összességében pozitív volt az események jelentésével kapcsolatban, azonban egy jelentős részük megemlítette a büntetéstől való félelmet. Sokan közülük pozitívan ítélték meg saját felügyelőjük/vezetőjük biztonsági intézkedéseit, és úgy vélték, hogy a transzfúziós szolgálatuk igyekszik felfedni a hibák okait. Azonban csak 31\%-uk értett egyet abban, hogy az ápolószemélyzetnek együtt kellene múködni a transzfúziós szolgálattal a hibák csökkentése érdekében. Ez a tanulmány hasznos információkkal szolgál arról, hogy a személyzet hogyan vélekedik a transzfúziós események jelentéséről, 
a biztonsággal kapcsolatos kérdésekről, és miként határozza meg az erősségeiket és a fejlesztendő területeket [16].

Egy másik közleményben a szerzők a transzfúziós reakciók ápolók részéről történő szorosabb megfigyelését javasolták. Ez azért nagyon fontos, mert ezeknél a reakcióknál a korai felismerés és az azonnali beavatkozás meghatározó jelentőségü [17].

A Blood Matters project 2002 áprilisában kezdődött Ausztráliában. A részt vevő intézmények a kórházakban zajló transzfúziós gyakorlat javítását tűzték ki célul, de tevékenységük eredményeként létrejött az úgynevezett transzfúziós nővér státusa a nagyvárosi és a főbb regionális kórházakban, valamint a Postgraduate Certificate in Transfusion Practice online kurzus elindítása, amelynek keretében ezeket a nóvéreket képzik [18].

Egy 2011-ben publikált kvalitatív kutatás a betegek szemszögéből foglalkozott a transzfúziós kezeléssel és azt igyekezett feltárni, hogy mennyire jól értik/értelmezik a vérátömlesztést, és hogy ez a kezelés milyen kényelmetlenséget okoz számukra. Ez a felmérés felszínre hozta a gyakorlat hiányosságait, gyengeségeit. A kutatók azt állapították meg, hogy az ápolók az orvosokhoz képest több tanácsot adtak a betegeknek a transzfúzióval kapcsolatban [19].

A szakirodalomból egyértelmü, hogy a transzfúziós terápiában folyamatosan nó az ápolók szerepe. Ezt azonban kizárólag komoly szakmai ismeretek, készségek birtokában és precíz munkavégzés esetén tölthetik be. Nem véletlenül hangsúlyozza az Egyesült Királyságban múködő Ápolói és Szülésznői Tanács (Nursing and Midwifery Council), hogy a vérkészítmények beadásánál a gyógyszereléshez hasonló követelményeket kell alkalmazni: az ápolónak nem elegendő mechanikusan végrehajtania az orvosi elő́rásokat, hanem folyamatosan át kell gondolnia az aktuális folyamatokat és szakmailag is meg kell tudnia ítélni a transzfúzió gyakorlatát [20].

Kutatásunkban egy országos szintű felmérés során szerettük volna feltérképezni a transzfúziós terápia hazai gyakorlatát, az ápolók ismereteit a transzfúziós terápiával és ezen belül az ápolási funkciókkal kapcsolatosan, továbbá azt, hogy az aktuális gyakorlat mennyire felel meg a 2008-ban kiadott Transzfúziós Szabályzat elő́rásainak. Jelen tanulmányunk a már validált, standardizált kérdőívvel történt felmérés adatainak leíró statisztikai elemzését mutatja be. Az ápolók tudás- és képességszintjének korszerű tesztelméleti módszerekkel történő mérésével egy további közleményben foglalkozunk.

Hipotéziseink az alábbiak voltak:

1. Feltételeztük, hogy az ápolók transzfuziológiai ismeretei kiválóak - tekintettel arra, hogy a hazai szinten érvényes Transzfúziós Szabályzat valamennyi osztályon elérhető a szakemberek számára -, azonban az ápolás önálló, nem önálló és együttmúködő funkcióinak meghatározása $60 \%$-uknál helytelen.

2. Véleményünk szerint a transzfúziós terápiával foglalkozó osztályokon az ápolók 90\%-a jól ismeri szakmai, jogi, etikai kompetenciáit a transzfúziós terápiában, azokon az osztályokon, ahol ritkábban fordul elő transzfúzió, ez az arány csupán 50\%-os.

3. Az intézmények között jelentős különbségek vannak a transzfúziós terápia gyakorlatára vonatkozóan, különös tekintettel az ápolási és egyéb idevonatkozó dokumentációk alkalmazására, a vércsoport meghatározásának eszközeire, valamint a vérmelegítés kivitelezésére vonatkozóan.

4. A vizsgálatba vont intézmények 70\%-a készítette el a saját „Kórházi transzfúziós eljárási utasítását”, amely a kórház minőségbiztosítási dokumentációs rendszerébe illesztett, a Transzfúziós Szabályzat figyelembevételével készült eljárásrend, és tartalmaznia kell a transzfuziológia minden egyes lépését, a folyamat különböző elemeinek felelőseit, valamint a dokumentálás módját.

5. Az osztályok csupán 20\%-án található hivatalosan megbízott transzfúziós felelős ápoló, akinek feladata a transzfúzióval kapcsolatos ápolói teendők ellenőrzése, koordinálása.

6. Véleményünk szerint az ápolók ismerik az intézményi transzfúziós eljárási rendet, de az osztályok mintegy $80 \%$-a nem rendelkezik helyi transzfúziós protokollal.

\section{Módszer}

A hazai kórházak/klinikák egyes betegosztályain dolgozó ápolók, vezető ápolók körében 2014. november 19. és 2015. február 20. közötti intervallumban végeztünk országos reprezentatív felmérést. Ennek során a vérátömlesztés helyi gyakorlatának jellemzőire és a transzfúziós terápiával kapcsolatos ismeretekre vonatkozóan gyưjtöttünk adatokat.

Kutatásunkhoz a kérdőíves felmérés módszerét választottuk, az adatgyújtés részben papíralapú, részben webalapú anonim, önkitöltős kérdőív alkalmazásával, valószínűségi, véletlen mintavételi módszerrel, rétegzett mintavételi technikával történt [21]. Vizsgálati mintánkba olyan ápolókat és vezetó ápolókat vontunk be, akik felnőtt fekvőbeteg-osztályon dolgoznak, rendelkeznek valamilyen egészségügyi szakképesítéssel és munkájuk során változó rendszerességgel, de aránylag gyakran vesznek részt transzfúziós terápiában. A mintába kerülés

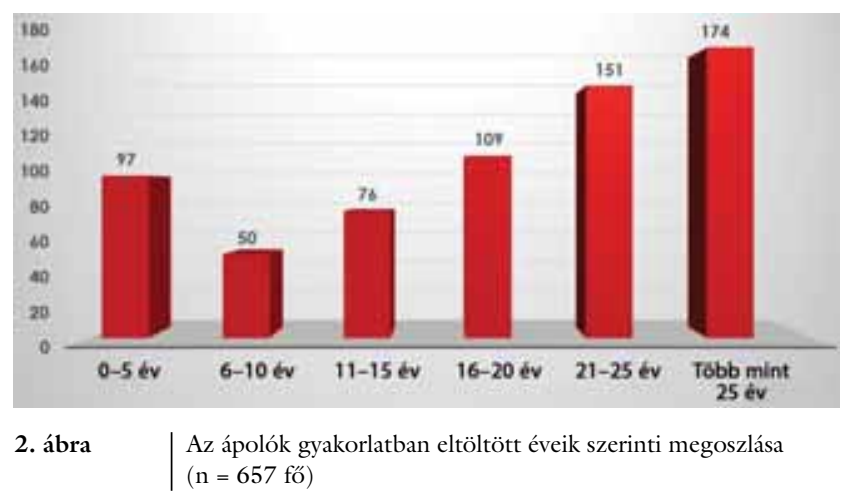


\begin{tabular}{l|l} 
1. táblázat & $\begin{array}{l}\text { A vizsgált minta transzfúziós terápiában történő részvételének } \\
\text { gyakorisága }\end{array}$
\end{tabular}

\begin{tabular}{lc}
\hline & Minta $(\mathrm{n}=657$ fó $)$ \\
\hline Naponta & 167 \\
Hetente & 202 \\
Kéthetente & 45 \\
Havonta & 69 \\
Ritkábban mint havonta & 174 \\
\hline
\end{tabular}

2. táblázat | A vizsgált minta iskolai végzettség szerinti megoszlása

\begin{tabular}{lc}
\hline & Minta ( $\mathrm{n}=657$ fơ) \\
\hline Egészségügyi szakiskola & 21 \\
Érettségi/egészségügyi & 49 \\
szakközépiskola & \\
OKJ-végzettség & 313 \\
Főiskolai végzettséget nem & 89 \\
tanúsító felsőfokú szakképesítés & \\
Főiskola & 165 \\
Egyetem & 20 \\
PhD & - \\
\hline
\end{tabular}

valamennyi kritériumának összesen $n=657$ fó felelt meg.

A mintába tartozó ápolók közül legtöbben (174 fó) több mint 25 éve dolgoznak az egészségügyben, őket követi a 21-25 éve dolgozók köre (151 fó) és legkevesebben ( 50 fó) a 6-10 éve dolgozók voltak, akik bekerültek a felmérésbe (2. ábra).

A résztvevők közül 478 fó osztályos ápolói, 123 fó osztályvezető ápolói és 56 fó részlegvezető ápolói munkakörben dolgozik a jelenlegi munkahelyén.

$\mathrm{Az}$ 1. táblázat szemlélteti, hogy a felmérésben részt vevő ápolók saját elmondásaik alapján milyen gyakorisággal végeznek transzfúziós terápiával kapcsolatos teendőket kórházi munkájuk során. A 2. táblázatban a résztve-

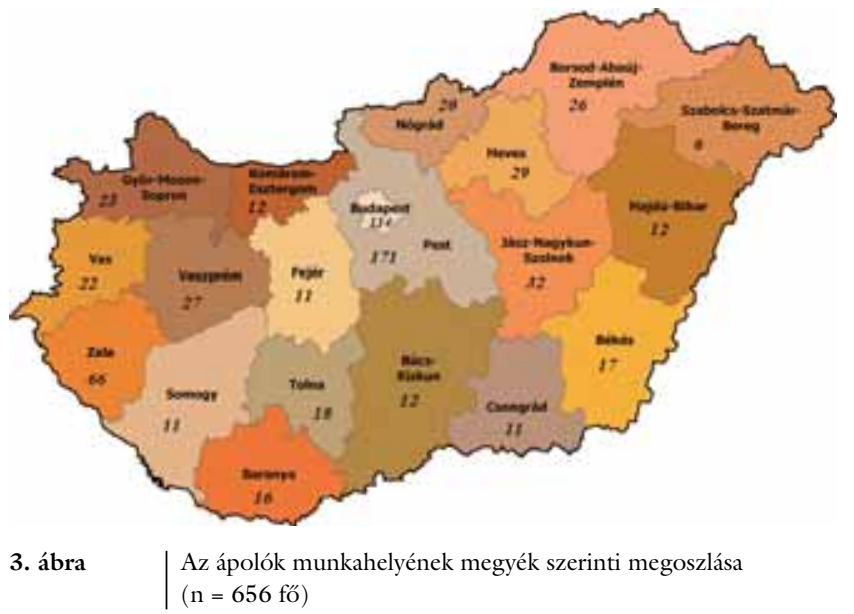

vők iskolai végzettség szerinti megoszlását tüntettük fel. Legtöbben OKJ-végzettséggel rendelkeztek, de a felmérésben viszonylag nagy arányban vettek részt fóiskolai végzettségü kollégák is. A részt vevő ápolók közül 147 fő rendelkezett, 510 fó viszont nem rendelkezett transzfúziós tanfolyammal. A munkahelyek megyénkénti megoszlását (3. ábra) illetően sorrendben a legtöbben Pest megyéből, Budapestról és Zala megyéből vettek részt a vizsgálatban. A legalacsonyabb részvételi arány SzabolcsSzatmár-Bereg megyében volt, innen csupán 6 fó vett részt a felmérésünkben, 1 fő nem jelölte meg, melyik megyében dolgozik.

\section{Kérdöí}

A kérdőív összeállításánál a felmérés időpontjában hatályos, 2008-as Transzfúziós Szabályzat irányelvei [3], a transzfúziós eljárás rendje, az ápolás szakmai, jogi, etikai aspektusának elemei, valamint a korábbi intézménylátogatások során szerzett közvetlen megfigyelés tapasztalatai voltak irányadóak. Tekintettel arra, hogy az Országos Vérellátó Szolgálat főigazgatója 2014 októberében - az országos felmérésünk kivitelezése céljából elkészített kérdőívünk tesztelését/retesztelését követően - hagyta jóvá a Transzfúziós Szabályzat címü módszertani levél aktualizált formanyomtatványokkal történő változatlan utánnyomását, eredményeinket a 2014-ben kiadott Transzfúziós Szabályzat előírásainak betartására is vonatkoztatjuk [22].

A felmérés során kiemelten vizsgáltuk az adott intézményben, osztályon alkalmazott transzfúziós terápia dokumentációit, a helyi protokoll meglétét és az ápolási dokumentáció vezetésének szakszerűségét. Fokozott figyelmet fordítottunk a transzfúziós terápiával kapcsolatos ápolói kompetenciákra. Vizsgáltuk a vérkészítmény igénylésének körülményeit, a pre- és poszttranszfúziós laboratóriumi vizsgálatok elvégzését, a transzfúziós szabályzatban történt változások követését, az ágy melletti vércsoport-meghatározás módját, a vérmelegítés eszközeit, a biológiai próba kivitelezését, a zsákok és szerelékek tárolását, a szövődmények dokumentálására vonatkozó helyi szokásokat.

A gyakorlatot ismerve elmondható, hogy általános hiba az önálló és nem önálló ápolói funkciók keverése. Ennek legfóbb oka, hogy az ápolási tevékenységeket nem az elrendelés, hanem a végrehajtás oldaláról közelítik meg, ezért a vérvételt, injekciózást, gyógyszerelést, EKG-készítést is az önálló funkciók közé sorolják csupán azért, mert önállóan hajtják végre. Valójában ezek a nem önálló funkciók közé tartoznak, és ezeket kizárólag orvosi utasításra, de önállóan és saját felelősségére végezheti az ápoló [23]. Kérdőívünkben, egy táblázatban 16 különféle, részben a transzfúziós terápiával is kapcsolatba hozható tevékenységet soroltunk fel, amelyek esetében az ápolóknak be kellett jelölniük, hogy az adott tevékenység az ápolás önálló, nem önálló vagy együttmúködő funkciójába tartozik-e. 
Ennek megfelelően a vizsgálati kérdőív három részből, összesen 29 kérdésből állt: I. szociodemográfiai (8 kérdés), II. a transzfúziós terápiával kapcsolatos ismeretekre vonatkozó (12 kérdés), III. a transzfúziós terápia gyakorlatára vonatkozó (9 kérdés). A felmérés során a negyedév alatt beérkező valamennyi kérdőív értékelhető volt.

A kérdőíves felmérés adatait az IBM SPSS (20. verzió) és a Microsoft Office 2013 programok segítségével értékeltük. A kutatás az adatvédelmi szabályok betartása mellett történt.

\section{Eredmények}

A vizsgálati eredményeket hármas bontásban ismertetjük. Először az ápolói ismereteket tekintjük át, majd azt mutatjuk be, hogy az ápolók mennyire vannak tisztában a különböző ápolói kompetenciákkal. Végül a jelenlegi intézményi transzfúziós gyakorlatról adunk áttekintést.

\section{A transzfúziós terápiával kapcsolatos ismeretek}

A kérdőívben 11 kérdés irányult a transzfúzióval kapcsolatos ismeretek felmérésére. Az egyes kérdések a vérátömlesztés különböző aspektusaira vonatkoztak, és együttesen lefedték mindazokat az alapvető ismereteket, amelyek nélkül az ápolók nem tudnak megbízhatóan részt venni a transzfúziós team munkájában. Az egyes kérdésekre adott helyes válaszok száma a 657 fős mintához hasonlítva képet ad a hazai ápolói transzfúziós ismeretek mértékéről.

594 ápoló $(90,41 \%)$ válaszolta helyesen azt, hogy a Transzfúziós Szabályzat tartalmaz Betegfelvilágositási és hozzájárulási nyilatkozatmintát. 379 fó $(57,68 \%)$ volt tisztában azzal, hogy az előzetes laboratóriumi vércsoport-szerológiai vizsgálathoz 24 (legfeljebb 72) órán belül levett 1 csö nativ és/vagy I csö alvadásban gátolt (EDTA) vérminta használható. A 3. táblázat a vérkészítmények szükséges beadási hőmérsékletére adott válaszokat szemlélteti. A résztvevők körülbelül harmada válaszolt helyesen. 444 fó $(67,58 \%)$ válaszolta helyesen, hogy a felmelegitett vérkészitmények beadását haladéktalanul kell megkezdeni. A „Transzfúzió előtti vérminta” helyes definícióját 209 fó $(31,81 \%)$ ismerte, 606 fó $(92,24 \%)$ sze-

3. táblázat |Vérkészítmények hőmérséklethatárával kapcsolatos válaszok megoszlása

\begin{tabular}{lc}
\hline & Minta $(\mathrm{n}=657$ fó $)$ \\
\hline $30-35{ }^{\circ} \mathrm{C}$ & 218 \\
$20-37^{\circ} \mathrm{C}$ & 227 \\
$30-40{ }^{\circ} \mathrm{C}$ & 37 \\
$20-30{ }^{\circ} \mathrm{C}$ & 175 \\
\hline
\end{tabular}

rint a klinikai AB0- és RhD-vércsoport-meghatározás kötelező a választott vér beadása előtt is. A „Klinikai vércsoport-meghatározás” kérdésnél 213 fő $(32,42 \%)$ jelölte meg a helyes választ.

A „Transzfúzió előtt a vércsoport-szerológiai vizsgálatokon kívül a beteg állapotának és a transzfúziós indikációnak megfelelően mely vizsgálatokat szükséges elvégezni?" kérdésnél 340 fó (51,75\%) az „általános vizeletvizsgálatot”, 627 fö $(95,43 \%)$ a „kardinális tünetek $(P, R R, T)$ mérését”, 501 fö $(76,25 \%)$ a „hemoglobinszint, vörösvérsejtszám ellenörzését”, továbbá 351 fó $(53,42 \%)$ a „hematokritérték ellenörzését” jelölte be helyesen.

568 ápoló $(86,45 \%)$ tudta helyesen, hogy „A transzfúzió teljes tartama alatt szükséges a beteg megfigyelése, amit az ápoló végezhet." 67 ápoló (10,2\%) úgy vélte, hogy a beteg megfigyelését kizárólag a transzfúzióért felelős orvos végezheti, 9 (1,37\%), illetve 13 (1,98\%) ápoló szerint a beteget nem szükséges megfigyelni a transzfúzió teljes tartama alatt (illetve csak a zsákok cseréjekor), és nincs jelentósége annak, hogy az ápoló vagy az orvos végzi ezt a feladatot.

A biológiai próbára vonatkozóan adott válaszalternatívákat és a válaszok megoszlását a 4. táblázat szemlélteti, a helyes választ dőlt, betúkkel jelöltük. A válaszadók kevesebb mint $26 \%$-a válaszolt helyesen erre a kérdésre.

A transzfúziós terápiát követő teendőkkel kapcsolatban az alábbiak szerint születtek helyes válaszok: 480 fó $(73,06 \%)$ tudta, hogy a transzfúzió után a beteget legalább két óráig javasolt megfigyelni. 456 ápoló $(69,40 \%)$ szerint a bent fekvö betegnél makroszkóposan ellenörizni

4. táblázat | A biológiai próbára vonatkozó válaszok megoszlása

Felnőtteknél az első 40 ml-t sugárban kell
transzfundálni, utána a transzfúziót lassú
cseppszámra kell beállítani, és a beteget 5
percig fokozottan meg kell figyelni.

$\operatorname{Minta}(\mathrm{n}=657$ fó $)$

Felnőtteknél az első 40 ml-t sugárban kell transzfundálni, utána a transzfúziót lassú cseppszámra kell beállítani, és a beteget 15 percig fokozottan meg kell figyelni.

Felnőtteknél az első 25 ml-t sugárban kell transzfundálni, utána a transzfúziót lassú cseppszámra kell beállítani, és a beteget 5 percig fokozottan meg kell figyelni.

Felnötteknél az elsö 25 ml-t sugárban kell transzfundálni, utána a transzfúziót lassú cseppszámra kell beállitani, és a beteget 15 percig fokozottan meg kell figyelni.

Felnőtteknél az első 20 ml-t sugárban kell transzfundálni, utána a transzfúziót lassú cseppszámra kell beállítani, és a beteget 5 percig fokozottan meg kell figyelni.

Amennyiben nincs panasza, a múveletet háromszor meg kell ismételni. 
Ápolási funkciók meghatározása az egyes ápolási tevékenységekkel kapcsolatban

\begin{tabular}{lrrr}
\hline Tevékenység & \multicolumn{3}{c}{ Ápolási funkciók } \\
\cline { 2 - 4 } & \multicolumn{1}{c}{ Ö } & \multicolumn{1}{c}{ NÖ } & \multicolumn{1}{c}{$\mathrm{E}$} \\
\hline Vérvétel & 387 & 191 & 79 \\
Kardinális tünetek (vérnyomás, pulzus, & 635 & 6 & 16 \\
hőmérséklet, légzés) mérése & & & \\
Oxigén adása & 238 & 254 & 165 \\
Infúzió bekötése & 199 & 230 & 228 \\
Transzfúzió bekötése & 10 & 225 & 422 \\
Vizelet-mintavétel laboratóriumi vizsgálatra & 461 & 150 & 46 \\
EKG-készítés & 466 & 140 & 51 \\
Biológiai próba elvégzése & 26 & 271 & 360 \\
Betegmegfigyelés & 585 & 20 & 52 \\
Injekciózás & 238 & 267 & 152 \\
Ápolási dokumentáció vezetése & 646 & 5 & 6 \\
Gyógyszerelés & 200 & 283 & 174 \\
Gyógyszeres fájdalomcsillapítás & 42 & 367 & 248 \\
Vizit & 37 & 100 & 520 \\
Vércsoport-meghatározás & 11 & 289 & 357 \\
Vérkészítmény melegítése & 118 & 108
\end{tabular}

Ö = önállóan végzett; $\mathrm{NÖ}=$ nem önállóan végzett;

$\mathrm{E}=$ együttmúk ödésben végzett.

kell a recipiens transzfúziót követo" 48 órán belüli vizeletét. 287 fö $(43,68 \%)$ szerint a vérátömlesztést követö két héten belül külön figyelmet kell forditani a hemolizisre utaló tünetekre, és 631 ápoló $(96,04 \%)$ volt tisztában azzal, hogy a transzfúzió után a használt, lezárt szereléket, a kiürült vérkészitményt zsákkal együtt meg kell ôrizni az erre a célra kijelölt hütöszekrényben 48 óráig.

\section{Az ápolási funkciókra vonatkozó ismeretek}

A kapott válaszokat az 5. táblázat mutatja be, amelyben kiemeléssel jelöltük a helyes válaszokat. Az „ápolási dokumentáció vezetését" kevés kivétellel a megkérdezettek egyöntetűen önálló ápolási funkciónak tartották. Ezenkívül még a „kardinális tünetek mérése” kapcsán sikerült magas arányban, hibátlanul meghatározni az ehhez kapcsolódó ápolási funkciót. A legmegosztóbb az „oxigén adása”, az „infúzió bekötése”, az „injekciózás” és a „gyógyszerelés” voltak, mindhárom típusú ápolási funkció nagyságrendileg hasonló számú szavazatot kapott, vagyis az ápolók harmada tudta, hogy ezek a tevékenységek a nem önálló funkciók közé tartoznak, noha önállóan hajtja végre az ápoló.

A transzfúziós terápiával foglalkozó osztályokon az ápolók ismeretei a transzfúziós terápiát illetô szakmai, jogi, etikai kompetenciáikkal kapcsolatban nem voltak sokkal jobbak azokénál, ahol ritkábban fordul elő transz-
6. táblázat $\mid$ Transzfúziós terápiával kapcsolatos kérdésekre adott helyes és helytelen válaszok aránya a transzfúziós terápiában való részvétel gyakoriságának függvényében

\begin{tabular}{|c|c|c|c|}
\hline \multicolumn{2}{|c|}{$\begin{array}{l}\text { A transzfúziós terápiával kapcsolatos } \\
\text { ismeretekre vonatkozó kérdések }\end{array}$} & \multicolumn{2}{|c|}{$\begin{array}{c}\text { Transzfúziós terápiában való } \\
\text { részvétel gyakorisága }\end{array}$} \\
\hline & & $\begin{array}{c}\text { Gyakran* } \\
\left(\mathrm{n}_{\mathrm{gy}}=414 \text { fó }\right)\end{array}$ & $\begin{array}{c}\text { Ritkán* } \\
\left(\mathrm{n}_{\mathrm{r}}=243 \text { fó }\right)\end{array}$ \\
\hline \multirow[t]{2}{*}{1} & Helyes válaszok aránya & $91,1 \%$ & $89,3 \%$ \\
\hline & Helytelen válaszok aránya & $8,9 \%$ & $10,7 \%$ \\
\hline \multirow[t]{2}{*}{2.} & Helyes válaszok aránya & $58,2 \%$ & $56,8 \%$ \\
\hline & Helytelen válaszok aránya & $41,8 \%$ & $43,2 \%$ \\
\hline \multirow[t]{2}{*}{3.} & Helyes válaszok aránya & $34,1 \%$ & $35,4 \%$ \\
\hline & Helytelen válaszok aránya & $65,9 \%$ & $64,6 \%$ \\
\hline \multirow[t]{2}{*}{4.} & Helyes válaszok aránya & $64,3 \%$ & $73,3 \%$ \\
\hline & Helytelen válaszok aránya & $35,7 \%$ & $26,7 \%$ \\
\hline \multirow[t]{2}{*}{5.} & Helyes válaszok aránya & $31,9 \%$ & $31,7 \%$ \\
\hline & Helytelen válaszok aránya & $68,1 \%$ & $68,3 \%$ \\
\hline \multirow[t]{2}{*}{6.} & Helyes válaszok aránya & $91,8 \%$ & $93,0 \%$ \\
\hline & Helytelen válaszok aránya & $8,2 \%$ & $7,0 \%$ \\
\hline \multirow[t]{2}{*}{7.} & Helyes válaszok aránya & $36,2 \%$ & $25,9 \%$ \\
\hline & Helytelen válaszok aránya & $63,8 \%$ & $74,1 \%$ \\
\hline \multirow[t]{2}{*}{8.} & Helyes válaszok aránya & $11,8 \%$ & $14,0 \%$ \\
\hline & Helytelen válaszok aránya & $88,2 \%$ & $86,0 \%$ \\
\hline \multirow[t]{2}{*}{9.} & Helyes válaszok aránya & $86,0 \%$ & $87,2 \%$ \\
\hline & Helytelen válaszok aránya & $14,0 \%$ & $12,8 \%$ \\
\hline \multirow[t]{2}{*}{10.} & Helyes válaszok aránya & $21,7 \%$ & $32,5 \%$ \\
\hline & Helytelen válaszok aránya & $78,3 \%$ & $67,5 \%$ \\
\hline \multirow{2}{*}{$\begin{array}{l}11 . \\
12 .\end{array}$} & Helyes válaszok aránya & $28,7 \%$ & $29,2 \%$ \\
\hline & Helytelen válaszok aránya & $71,3 \%$ & $70,8 \%$ \\
\hline \multirow[t]{2}{*}{ Összesen } & Helyes válaszok átlagosan & $50,53 \%$ & $51,66 \%$ \\
\hline & $\begin{array}{l}\text { Helytelen válaszok } \\
\text { átlagosan }\end{array}$ & $49,47 \%$ & $48,34 \%$ \\
\hline
\end{tabular}

*Gyakran - napi, heti szinten vagy kéthetente vesznek részt transzfúziós terápiában.

Ritkán - havonta vagy ennél ritkábban vesznek részt transzfúziós terápiában.

fúzió. Ezen hipotézisünk vizsgálatához kereszttáblaelemzést végeztünk két nominális változó (a transzfúziós terápiával kapcsolatban feltett kérdések - sorváltozó, és a transzfúziós terápiában való részvételi gyakoriság - oszlopváltozó) esetében. $2 \times 2$-es kereszttáblákat készítettünk, majd a kontingenciatáblázatok összesített eredményeit a 6. táblázatban összesítettük.

\section{A transzfúziós terápia belyi gyakorlatára vonatkozó vizsgálati eredmények}

$\mathrm{Az}$ intézményekben található transzfúziós infrastruktúraelemeket illetően a vizsgált mintában 64 helyen múködik kórházi transzfúziós osztály, 116 helyen transzfúziós 
részleg, 373 helyen van vérdepó, 452 intézményben van helyi protokoll, 472 helyen transzfúziós felelös orvos, jóval kevesebb helyen (164) felelős ápoló és 108 intézményben müködik transzfúziós bizottság.

Elsőként azt kérdeztük, hogy ki végzi a vércsoportmeghatározást azon a betegosztályon, ahol a válaszadó kolléga dolgozik. 601 fó $(91,47 \%)$ szerint „mindig az orvos”, 10 fő $(1,52 \%)$ válasza alapján „mindig az ápoló”, míg további 46 személy (7\%) válaszolta azt, hogy az „orvosok is és az ápolók is szoktak vércsoportot meghatározni".

537 fö $(81,73 \%)$ válasza alapján „Serafol kártya” segítségével, 53 fö $(8,06 \%)$ válasza alapján „Eldoncard kártya segítségével”, 51 fö $(7,76 \%)$ szerint pedig „kártyás és csempés" módszerrel is történik osztályukon az ágy melletti vércsoport-meghatározás. 16 ápoló $(2,43 \%)$ válasza alapján ezt a régi „csempés” módszerrel végzik.

A vérkészítmények osztályra történő érkezése kapcsán igencsak változatos képpel találkoztunk. 543 fő $(82,65 \%)$ elmondása alapján „az osztályukra a vérkészítmények hőszigetelt táskában/ládában érkeznek, hưtve (például: plazma) vagy szobahőmérsékleten (például: thrombocytakészítmények)". 28 ápoló (4,26\%) elmondása szerint a vérkészítmények egy táskában érkeznek, a táskában lévő hőmérséklet nem lényeges. 69 fő (10,5\%) válaszolta azt, hogy a vérkészítményeket kézben hozzák az osztályukra. 17 fó $(2,58 \%)$ szerint a vérkészítmények egyéb módon érkeznek, például a transzfúziós nővér által előkészítve, szerelékezve, „beadásra készen, kis kocsin, betegenként kosarakba helyezve”; „kosárban”; „kézben hozva érkeznek, de nejlontasakban hütőből kivéve”; „csőpostán keresztül”; „az osztályunkon üzemel a vérdepó”; „csőpostán keresztül, szigetelt tartóban".

A vérkészítmények felmelegítésének gyakorlatára szintén kíváncsiak voltunk. Ennél a kérdésnél többen több válaszlehetőséget is bejelöltek. A kapott válaszok alapján 290 fö szerint „A vérkészítményeket a védőtasakjukkal együtt vízhőmérővel ellenőrzött, tartósan $37^{\circ} \mathrm{C}$-os vízfürdőben melegítik fel”. 236 fő szerint: „A vérkészítményeket vérmelegítő készülékkel (például: VM-1 típusú, Barkey Plasmatherm, Hotline típusú készülék) melegítik fel.” További 218 fö válasza alapján: „A vérkészítményeket szobahőmérsékleten hagyják addig, amíg beadásra nem lesz megfelelő a hőmérséklete.” 11 ápoló szerint: „A vérkészítményeket a radiátorra helyezve melegítik fel.” 12 ápoló szerint pedig: „A vérkészítményeket egyéb módon melegítik fel." Néhány példa ez utóbbira vonatkozóan: „vízfürdőben - hőmérséklet nem ellenőrzött”; "a vérkészítményeket a radiátorra helyezve melegítjük fel”; „vízfürdő érzés alapján, illetve vérmelegítő is"; „más osztályon felmelegítik a megfelelő hőmérsékletre”; „plazmát az intenzív osztályon melegítik fel”; „lavórban, langyos vízben”; „vízfürdőben, de hőmérés nélkül”; „meleg víz (kézmeleg)”; „vesetálba tesszük csomagolással együtt, s meleg vizet engedünk rá”; „vérellátó melegíti”, „dialízisgép felmelegíti”.
Az egyes betegosztályokra jellemző biológiai próba kivitelezésével kapcsolatban a következő információkhoz jutottunk. 412 ápoló válasza alapján a biológiai próbát az orvos zsákonként egyszer végzi el, 41 ápoló válasza alapján kétszer, illetve 114 ápoló szerint pedig három alkalommal. 34 ápoló válaszolta azt, hogy a biológiai próbát nem minden alkalommal végzik el. 75 ápoló számolt be arról, hogy az osztályukon a biológiai próbát nem az orvos, hanem az ápoló végzi el. 7 ápoló válasza alapján az derült ki, hogy az adott osztályon egyéb módon történik a biológiai próba (például: „Egyszer az orvos által a bekötésnél, és kétszer a nővér által”; „Az elsőnél van ott orvos, a többit az ápoló végzi”; stb.).

Többféle választ kaptunk arra a kérdésünkre, hogy miként történik a vérkészítmények bekötése az adott osztályon. 247 ápoló jelölése alapján a vérkészítmények bekötését az ápolók végzik, orvosi felügyelettel, 311 ápoló szerint ez kizárólag az orvosok feladata. 43 ápoló jelölése alapján a vérkészítmények bekötését az ápolók végzik önállóan, míg 56 ápoló szerint a vérkészítmények bekötését orvosok és ápolók egyaránt végzik.

Szintén többféleképpen történik a vérkészítmények tárolása a transzfúziót követően az egyes osztályokon. 565 fö válaszolta, hogy: „A transzfúziót követöen 48 órán át hütốben tárolják a zsákokat, szerelékeket.” 68 fó szerint: „A transzfúziót követően 24 órán át hütőben tárolják a zsákokat, szerelékeket.” 18 fő válasza alapján: „A transzfúziót követően 24-48 órán át a veszélyes hulladékgyűjtő dobozban tárolják a zsákokat, szerelékeket.” 6 fo" leírásában szerepel egyéb tárolási mód (például: „műtét után visszaküldjük a TRX-laborba”, „24 órán át, de nem a hütőben”, „szobahőmérsékleten, egy tálcán” stb.).

Felmérésünkben a következő jellemzőket találtuk az egyes betegosztályokon vezetett ápolási dokumentációkra vonatkozóan: 496 fő jelölése alapján az ápolási dokumentációban a transzfúziós terápia jelölése egységes, a jól láthatóság érdekében megkülönböztető piros színt használnak erre a célra. 118 fó hasonlóan egységes jelölésről számol be külön szín használata nélkül. 30 fő válasza alapján pedig a transzfúziós terápiát minden ápolókolléga úgy jelöli, ahogy szeretné vagy lehetősége van rá. 3 ápoló válaszolta azt, hogy a transzfúziós terápiát csak az orvosi dokumentációban jelölik. További 10 fó a fentiektől eltérő jelölésről számolt be. Néhány példa ezekből: napi transzfúziós lapot a beteget megfigyelő nővér tölti ki, vérminta száma+pirossal a bekötési idő, a 24 órás észlelőlapon az orvos jelzi a mennyiség/egység megjelölésével és a vérkészítmény azonosítókódjával, az ápoló a napi decursusban jelzi szöveges formában az ápolási dokumentáción belül stb.

Arra vonatkozóan is végeztünk felmérést, hogy milyen típusú dokumentumokat használnak az egyes osztályokon/intézményekben a transzfúziós terápia kapcsán. Ebben az esetben is több válasz bejelölésére volt lehetősége a résztvevőknek. A 7. táblázatban foglaltuk össze a válaszokat. 
7. táblázat |A transzfúziós terápiában használt dokumentumok a vizsgált mintában

\begin{tabular}{|c|c|}
\hline & $\operatorname{Minta}(\mathrm{n}=657$ fó $)$ \\
\hline A transzfúziós terápiába beleegyező nyilatkozat & 616 \\
\hline $\begin{array}{l}\text { Megtagadó nyilatkozat (általános, bármilyen } \\
\text { vizsgálat megtagadását vagy magát a } \\
\text { transzfúziós terápia megtagadását teszi } \\
\text { lehetóvé) }\end{array}$ & 253 \\
\hline Transzfúziós napló (papír vagy elektronikus) & 559 \\
\hline Észlelőlap transzfúzió esetén & 509 \\
\hline $\begin{array}{l}\text { Beteg-hazabocsátási tájékoztató (azon betegek } \\
\text { kapják, akik az osztályon való tartózkodásuk } \\
\text { idején transzfúziós terápiában részesültek) }\end{array}$ & 161 \\
\hline $\begin{array}{l}\text { Transzfúziós orvos/ } \\
\text { ápoló megbízásának formanyomtatványa }\end{array}$ & 210 \\
\hline Egyéb dokumentum(ok) & 20 \\
\hline
\end{tabular}

Eredményeink alapján egyértelmű, hogy „A transzfúziós terápiába beleegyező nyilatkozat”, valamint a „Transzfúziós napló (papír vagy elektronikus)” használata a leggyakoribb, ugyanakkor a „Beteg-hazabocsátási tájékoztatót”, valamint az „Egyéb dokumentumokat” ritkán jelölték meg.

\section{Megbeszélés}

Eredményeink alapján megállapítottuk, hogy az ápolók transzfuziológiával kapcsolatos ismeretei, sajnos, erősen hiányosak. Ez annak ellenére igaz, hogy a hazai szinten érvényes Transzfúziós Szabályzat valamennyi osztályon elérhető a szakemberek számára.

A vizsgált minta közel felénél (278 fő) voltak hiányosak a vércsoport-szerológiai vizsgálathoz szükséges vérminta levételével kapcsolatos ismeretek. A válaszadók túlnyomó többsége (430 fó) helytelenül tudta a vérkészítmények beadást megelőző hőmérséklethatárát, és egyharmada (213 fó) nem tudta, hogy a felmelegített vérkészítmények beadását haladéktalanul meg kell kezdeni. Kétharmaduk (448 fő) nem ismerte a „transzfúzió előtti vérminta” fogalmát, és nem tudta, hogy mi a klinikai vércsoport-meghatározás (444 fó). 83 fó kivételével, közel a teljes minta ( 574 fó) ismerete hiányos volt - a transzfúzió előtti vércsoport-szerológiai vizsgálatokon kívül - a beteg állapotának és a transzfúzió indikációjának megfelelő vizsgálatokkal kapcsolatban. Kétharmaduknak helytelen ismeretei voltak a „biológiai próbára” (488 fó), valamint a transzfúziós terápiát követő teendőkre vonatkozóan (467 fó). Az ápolási funkciók terén is elég nagy a káosz az ápolók ismereteit illetően. A legtöbb ápoló hibásan végezte el a következő tevékenységek ápolási funkciók szerinti rendszerezését: vérvétel (466 fő), oxigén adása (402 fő), infúzió bekötése (427 fö), vizelet-mintavétel laboratóriumi vizsgálatra (507 fö), EKG-készítés (517 fő), injekciózás (390fő), gyógy- szerelés (374 fö) és vérkészítmény melegítése (539 fő). Az eredmények alapján kimondhatjuk, hogy első hipotézisünk nem igazolódott.

A transzfúziós terápia szakmai, jogi, etikai kompetenciáival kapcsolatban kereszttábla-elemzést végeztünk, és a kontingenciatáblázatok összesített adatai alapján nem találtunk érdemi különbséget az ápolók ismereti szintje és a transzfúziós terápiában való részvétel gyakorisága között. A transzfúziós terápiában gyakran (naponta, hetente, kéthetente) részt vevő ápolók transzfúziós terápiával kapcsolatos ismeretszintje 50,53\%, a transzfúziós terápiában ritkán (havonta vagy annál ritkábban) résztvevőké $51,66 \%$ volt, ezért második hipotézisünket is elvetettük.

A transzfúziós gyakorlat helyi szokásait tekintve a legtöbb probléma a vérkészítmények felmelegítésével (496 esetben történik szabálytalanul), a vérkészítmények bekötésével (346 esetben történik szabálytalanul), valamint az alkalmazott dokumentációkkal (609 esetben volt hiányos a lista) kapcsolatban volt megfigyelhető. A biológiai próba kivitelezése sem tökéletes, az ápolók egyharmadának (252 fö) válasza alapján inkorrekt gyakorlatra következtettünk. A vérkészítmények osztályra érkezése szintén problematikus, 114 esetben nem a szabályoknak megfelelően történik. A transzfúziós terápia kapcsán alkalmazott ápolási dokumentációk használata és vezetése nem egységes, és 161 esetben nem volt megfelelő. Az intézmények között jelentős különbségek találhatók a transzfúziós terápia gyakorlatára vonatkozóan, különös tekintettel az ápolási és egyéb idevonatkozó dokumentációk alkalmazására, a vércsoport meghatározásának eszközeire, valamint a vérmelegítés kivitelezésére és az eszközparkra vonatkozóan, így harmadik hipotézisünk igazolódott.

A felmérésben részt vevő ápolók munkahelyének 70,32\%-a készítette el saját „Kórházi transzfúziós eljárási utasítását” a kórház minőségbiztosítási dokumentációs rendszerébe illesztett, a Transzfúziós Szabályzat figyelembevételével készült eljárásrendjét, tehát negyedik hipotézisünket is igazoltnak tekintjük.

„Osztályos transzfúziós felelős ápoló” az osztályok 23,9\%-án tevékenykedik, emiatt ötödik hipotézisünket el kell vetnünk.

Végezetül felmérésünk során megállapítottuk, hogy az ápolók transzfúziós terápiával kapcsolatos ismerete hiányos, de az osztályokon elég magas arányban - 462 ápoló $(70,32 \%)$ igenlő válasza alapján - készült már el helyi transzfúziós protokoll, tehát hatodik hipotézisünket is elvetjük.

A feltárt problémák alapján a megoldást az ápolás vezetőinek a transzfúziós terápia ápolási vonatkozásainak a jelenleginél nagyobb mértékű felügyeletében, a megfelelő transzfuziológiai képzés és rendszeres továbbképzés biztosításában látjuk. A jól képzett ápolók szakmai felelőssége, készségei, alkalmazásképes tudása jelentősen növelhető, ezáltal a betegek biztonsága is fokozható. 
Anyagi támogatás: A közlemény megírása, illetve a hozzá kapcsolódó kutatómunka anyagi támogatásban nem részesült.

Szerzôi munkamegosztás: R. V.: A szakirodalmi rész feldolgozása, kutatási cél, tárgy, hipotézisek kidolgozása, a vizsgálat előkészítése és lefolytatása, a statisztikai elemzések végzése, diagramok és táblázatok készítése, a kézirat megszövegezése. Cs. M.: A vizsgálat előkészítése, a kézirat megszövegezése. D. T.: Tanácsadás a statisztikai elemzésekhez. M. J.: Tanácsadás. A cikk végleges változatát valamennyi szerző elolvasta és jóváhagyta.

Érdekeltségek: A szerzőknek nincsenek érdekeltségeik.

A kézirat Rajki Veronika PhD-kutatásához kapcsolódik, amelynek témavezetője dr. Mészáros Judit.

\section{Irodalom}

[1] Vagner, M.: Patient safety in transfusion therapy. [Betegbiztonság a transzfúziós terápiában.] 2011. http://semmelweis.hu/emk/ files/2011/01/Vagner_PBS_12BF.pdf [Hungarian]

[2] Nursing Drug Handbook. Lippincott Williams \& Wilkins, Philadelphia, 2012.

[3] Barótiné Tóth, K., Csernus, Z., Hoffer, I., et al. (eds.): Blood Transfusion Policy: Methodological letter of the Hungarian National Blood Transfusion Service, 2nd edition. [Transzfúziós Szabályzat: Az OVSZ módszertani levele, 2. kiadás.] Országos Vérellátó Szolgálat, Budapest, 2008. [Hungarian]

[4] Stainsby, D., Jones, H., Asher, D., et al.: Serious hazards of transfusion: A decade of hemovigilance in the UK. Transfus. Med. Rev., 2006, 20(4), 273-282.

[5] Lessons for Clinical Staff from the 2007 SHOT Report. http:// www.shotuk.org/wp-content/uploads/2010/03/SHOT-lessons-for-clinical-staff-website.pdf

[6] Right blood, right patient, right time - Royal College of Nursing guidance for improving transfusion practice. 2013. http://www. rcn.org.uk/_data/assets/pdf_file/0009/78615/002306.pdf

[7] SHOT Report, Summary and Supplement 2013. http://www. shotuk.org/wp-content/uploads/SHOT-Summary-2013-Final.pdf

[8] Annual SHOT Report 2013 Supplementary Information. http://www.shotuk.org/wp-content/uploads/Chapter4-Summary-of-Main-Findings-and-Cumulative-Results-Supplementary-Information-2013.pdf

[9] Boyce, N., Brook, C.: 'Towards better, safer blood transfusion'. 2005. http://docs.health.vic.gov.au/docs/doc/8C312BB358 B9378DCA2578E30022218A/\$FILE/better-safer-transfusion.pdf

[10] Dzik, W. H.: Emily Cooley Lecture 2002: Transfusion safety in the hospital. Transfusion, 2003, 43(9), 1190-1199.

[11] Gray, A., Melchers, R.: Transfusion nurses - the way forward (serious hazards of transfusion annual report 2001-2002). SHOT, Manchester, 2003. www.shotuk.org
[12] Hobberger, C., Davis, R., Briggs, L., et al.: Applying radio-frequency identification (RFID) technology in transfusion medicine. Biologicals, 2012, 40(3), 209-213.

[13] Briggs, L., Davis, R., Gutierrez, A., et al.: RFID in the blood supply chain - increasing productivity, quality and patient safety. J. Healthcare Inf. Manag., 2009, 23(4), 54-63.

[14] RFID labels. http://www.siemens.com/press/pool/de/pressebilder/2010/photonews/300dpi/PN201005/PN20100502_300dpi.jpg https://rtvs.files.wordpress.com/2010/10/ banners_home_thumb.png? $=333 \& \mathrm{k}=177$

[15] Jimenez-Marco, T., Clemente-Marin, G., Girona-Llobera, E., et al.: A lesson to learn from Hemovigilance: The impact of nurses' transfusion practice on mistransfusion. Transfus. Apher. Sci., 2012, 47(1), 49-55.

[16] Sorra, J., Nieva, V., Fastman, B. R., et al.: Staff attitudes about event reporting and patient safety culture in hospital transfusion services. Transfusion, 2008, 48(9), 1934-1942.

[17] Bielefeldt, S., DeWitt, J.: The rules of transfusion: Best practices for blood product administration. Am. Nurse Today, 2009, 4(2), 27-30.

[18] Handbook for Transfusion Practitioners. 2010. http://resources. transfusion.com.au/cdm/singleitem/collection/pl669lcolll/ $\mathrm{id} / 19 / \mathrm{rec} / 1$

[19] Weiss Adams, K., Tolich, D.: Blood transfusion: The patient's experience. Am. J. Nurs., 2011, 111(9), 24-30.

[20] Nursing and Midwifery Council: Standards for medicines management, NMC, London, 2007. http://www.nmc-uk.org/ Documents/NMC-Publications/NMC-Standards-for-medicines-management.pdf

[21] Falus, I.: Introduction to the methods of pedagogical research. [Bevezetés a pedagógiai kutatás módszereibe.] Műszaki Könyvkiadó, Budapest, 2004. [Hungarian]

[22] Baróti-Tóth, K., Csermus, Z., Hoffer, I., et al. (eds.): Blood Transfusion Policy: Methodological letter of the Hungarian National Blood Transfusion Service. Unchanged reprint of the 2nd edition with updated forms. [Transzfúziós Szabályzat: Az OVSZ módszertani levele, a 2 . kiadás változatlan utánnyomása aktualizált formanyomtatványokkal.] Országos Vérellátó Szolgálat, Budapest, 2014. http://www.ovsz.hu/sites/ovsz.hu/files/kepzes/szakmai_anyagok/transzfuzios_szabalyzat_2._kiadas/transzf-szab-verz_76_2_ujra_nyomas_jav_nyomtatv_20140912.pdf. [Hungarian]

[23] Csóka, M.: The implementation of the nursing activity, independent, dependent and interdependent functions of nursing care. In: Székely, A., Hollós, S., Csóka, M. (eds.): Clinical fundamentals of intensive care units. [Az ápolási tevékenység végrehajtása, az ápolás önálló, nem önálló, és együttmưköőő funkciói. In: Székely, A., Hollós, S., Csóka, M. (szerk.): Intenzív terápiás osztályok klinikai alapismeretei.] Semmelweis Egyetem, Egészségtudományi Kar, Budapest, 2013. [Hungarian]

(Rajki Veronika

Budapest, Vas utca 17., 1088 e-mail: rajki.veronika@se-etk.hu) 